\title{
The Programme for International Student Assessment Research in Indonesia
}

\author{
Musafir Rastuti, Rully Charitas Indra Prahmana* \\ Universitas Ahmad Dahlan, Jl. Pramuka No. 42, Pandeyan, Umbulharjo, Yogyakarta, Indonesia \\ *rully.indra@mpmat.uad.ac.id
}

\begin{abstract}
Several Programme for International Student Assessment (PISA) research articles published in Indonesia have contributed to PISA research development in Indonesia, with mathematics as one of the PISA domains. However, there is no research to categorize the PISA research article to give future PISA researchers essential information. Therefore, this study aims to organize PISA research in Indonesia in the period 2016-2020. This study uses the Systematic Literature Review (SLR). The SLR method identifies, analyzes, evaluates, and categorizes specific topics related to PISA research in Indonesia. The research data comes from 27 articles published in thirteen accredited journals in the Sinta 1 and Sinta 2 category by the Ministry of Research, Technology and Higher Education of the Republic of Indonesia as an achievement for review journals, which have excellent management and publication quality. The findings indicated that nine categories were identified in this study, including the PISA articles dominance, the development of PISA model math problems, PISA research and subjects, the research methods, the content and context, students' abilities, and the level of the questions. Lastly, this research contribution also is intended to guide future PISA researchers in determining PISA research trends and the following PISA research opportunities in Indonesia.
\end{abstract}

Keywords: Indonesia, PISA research, systematic literature review

Received: April 5, 2021 / Accepted: May 24, 2021 / Published Online: June 1, 2021

\section{Introduction}

The Program for International Student Assessment (PISA) is a survey conducted every three years on the knowledge and skills of 15-years-old organized by the Organization for Economic Co-operation and Development (OECD, 2010). The PISA test is an international program with test categories namely reading, mathematics, and science. PISA assessment not only ensures students can reproduce knowledge, but also checks how well students can explore from what they have learned (OECD, 2017). Therefore, students can apply this knowledge to global problems.

The results of PISA reflect the fact that in modern times it gives appreciation to individuals not for what they already know, but for what they have done. Based on what they already know (OECD, 2017). This PISA assessment is not only in the form of questions regarding reading, math, and science literacy, but also a questionnaire to explore information on demographic, social, economic, and educational aspects (OECD, 2016). Strict quality 
assurance mechanisms are implemented in translation, sampling, and data collection (OECD, 2016). Thus, the PISA results have high validity and reliability.

Research on PISA has been widely carried out in Indonesia (Stacey, 2011; Murdaningsih \& Murtiyasa, 2016; Suprapto, 2016). This research is like the view of PISA in Indonesia. The development of PISA questions both in terms of content and context. The history of the development of PISA in Indonesia began with the publication of articles on PISA in JME (Journal on Mathematics Education), which is one of the accredited national journals in Indonesia. The article was entitled "The PISA Views of Mathematics Literacy in Indonesia" which was published in 2011 by Kaye Stacey (Stacey, 2011). PISA continues to develop in Indonesia, it can be seen from the increasing number of studies on PISA that have been published in various national journals in Indonesia.

Numerous PISA research articles published in Indonesia have contributed to the development of PISA research in the country (Thien, Darmawan, \& Ong, 2015; Suprapto, 2016). Some of these articles include "Mathematics Skill of Fifteen Years Old Students in Yogyakarta in Solving Problems Like PISA" (Wulandari, 2018), this research discusses the mathematical skills of students in solving questions on the PISA model. "Soft Tennis and Volleyball Context in the Asian Games for PISA-LIKE Mathematics Problems" (Jannah, Putri, \& Zulkardi, 2019), that research produced a product in the form of PISA model questions in the context of Asian Games tennis and volleyball that are valid, practical, and affect potential. Putra, Zulkardi, and Hartono (2016) conducted research entitled "Development of Mathematical Problem PISA Model Level 4,5,6 using Lampung Context", with the resulting product is 15 items of PISA model level 4,5,6 which are valid, practical, and has a potential effect. From the various articles above, no article has yet collected or categorized the PISA classification in Indonesia.

Researchers have widely used the Systematic Literature Review (SLR) method to synthesize research systematically, transparent, and reproducible (Parris \& Peachey, 2013). Prahmana, Sagita, Hidayat, and Utami (2020) have reviewed Realistic Mathematics Education (RME) article research for 20 years. The study classified the articles of the RME research based on seven categories, namely the dominance of the RME article, the RME research subject, the mathematics topic, the student's abilities, the RME term, and the research methods used in the RME article. Park, Bouck, and Josol (2020) using an SLR to conduct a survey related to skills maintenance in mathematics for individuals with intellectual disabilities. Hoosyar et al. (2020) also use the SLR method in reviewing open learning models 
in supporting independent learning in higher education. Therefore, this method is relevant to conduct a systematic review for a specific topic.

However, from several SLR studies that researchers have conducted, no one has investigated research on the topic of PISA. Therefore, researchers want to research or conduct surveys with different issues, namely the Program for International Student Assessment (PISA). The researchers would like to analyze and classify all articles that have been published in 13 Mathematics Education journals indexed by Sinta 1 and Sinta 2, to obtain a comprehensive classification of PISA-related research in Indonesia.

The research contributions are that it can provide detailed information on trends in PISA research in Indonesia over the past five years, so it becomes a recommendation and provides essential information as a fundamental idea for the following PISA research. The trends referred to are the research methods used, the focus of the problem, the content, and the context used in PISA research in Indonesia.

\section{Method}

The method used is a Systematic Literature Review (SLR). It is a method for identifying, evaluating and interpreting all relevant research sources related to the topic under study (Calderon \& Ruiz, 2015). We use samples from eight journals accredited by the Ministry of Research, Technology, and Higher Education of the Republic of Indonesia. From thirteen journals accredited in the Sinta 1 and Sinta 2 categories, where these categories have accreditation ranks 1 and 2 in the quality of management and excellent publication, eight journals provide the research paper with the PISA topic. In the Sinta 1 category, there is Journal Mathematics Education (JME). Furthermore, there are seven journals in the category Sinta 2, Jurnal Riset Pendidikan Matematika (JRPM), Infinity Journal, Jurnal Pendidikan Matematika (JPM), Jurnal Elemen, JRAMathEdu (Journal of Research and Advances in Mathematics Education), AKSIOMA: Jurnal Program Studi Pendidikan Matematika, and Kreano: Jurnal Matematika Kreatif-Inovatif.

Journal articles were analyzed using a comprehensive approach to identify all studies that fit the PISA research criteria. The research analysis begins by looking for PISA, Mathematical Literacy, and Context in each journal in eight accredited journals with the highest rank by the Ministry of Research, Technology, and Higher Education of the Republic of Indonesia. A total of 27 articles have been collected at this stage. Then classify all 
contributions from the article, such as title, year, journal name, problem focus, research method, research subject, content, context, math ability, and problem level.

This article aims to conduct a comprehensive study of existing PISA research in Indonesia in the last five years from 2016-2020. The papers submitted are analyzed comprehensively, categorized, compared, and divided into several main topics. The presentation of categories in PISA articles is based on the dominance of published PISA articles, the focus of the problem under study, research methods, and research subjects.

Further studies regarding the content used in the research on the development of mathematical problems in the PISA model, the context used in the study on the development of mathematical problems in the PISA model, the level of questions developed, and the measured mathematical abilities. In each section, there is a percentage of the contribution given to each category. In this article, researchers took a sample of PISA articles published in international journals in the last five years to compare PISA articles in Indonesia. In the last part, there is a table of resumes of PISA research articles in Indonesia

\section{Results and Discussion}

\section{Trends in PISA Articles in Several Journals in Indonesia}

The PISA publication trend from 8 journals from 2016 to 2018 did not experience an increase, but there was an increase in the number of articles in 2019 which were spread across Aksioma, Elemen, JME, JRAMathEdu, and JRPM. But then publication decreased $50 \%$ in 2020. Based on the number of PISA article releases every year, JME and JPM are journals that consistently produce articles with PISA scope. PISA publication trends during the 20162020 period are presented in Figure 1.

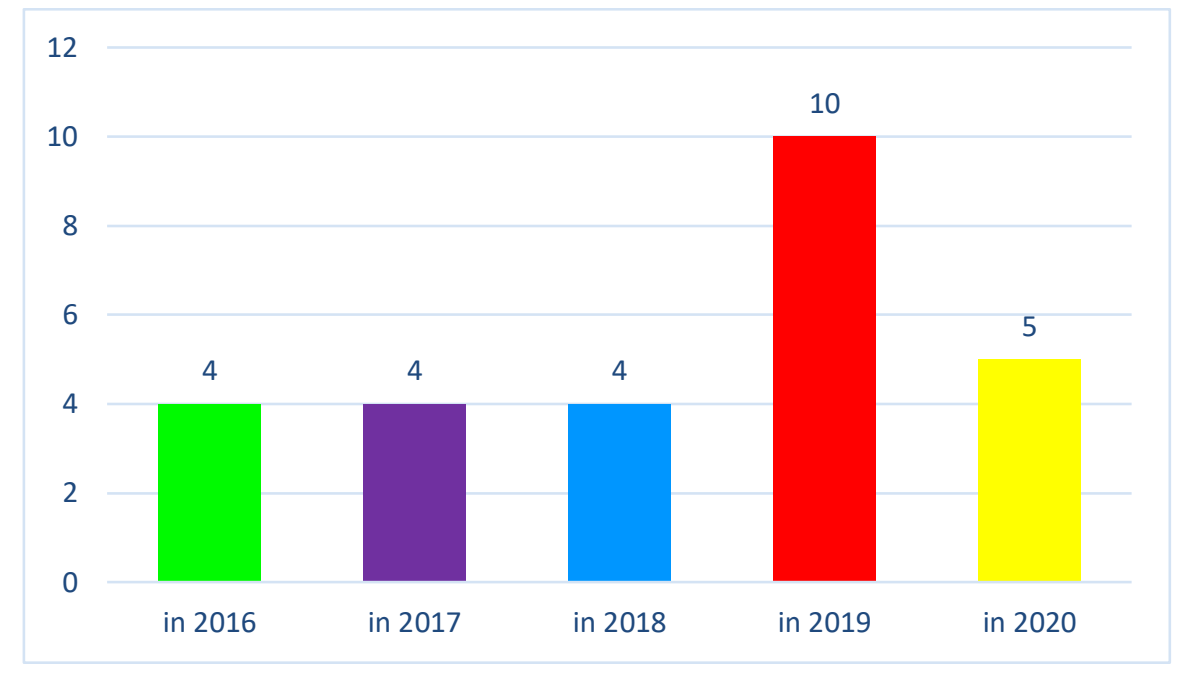

Figure 1. PISA's articles publication trends during 2016-2020 
The number of PISA articles published by JME is 7 articles in the past five years. The first PISA article was also published in JME in 2011. This article written by Stacey (2011) described the view of PISA based on the domain of mathematical literacy in Indonesia.

Based on the results of the analysis, the dominance of PISA articles is in JME and JPM. PISA articles in JME are nearly one-third of all PISA articles, whereas in JPM it is nearly one-fifth of all PISA articles. From all the journals that contain PISA articles, the focus and scope of each journal is in the field of mathematics education. PISA articles in each journal are featured in Figure 2.

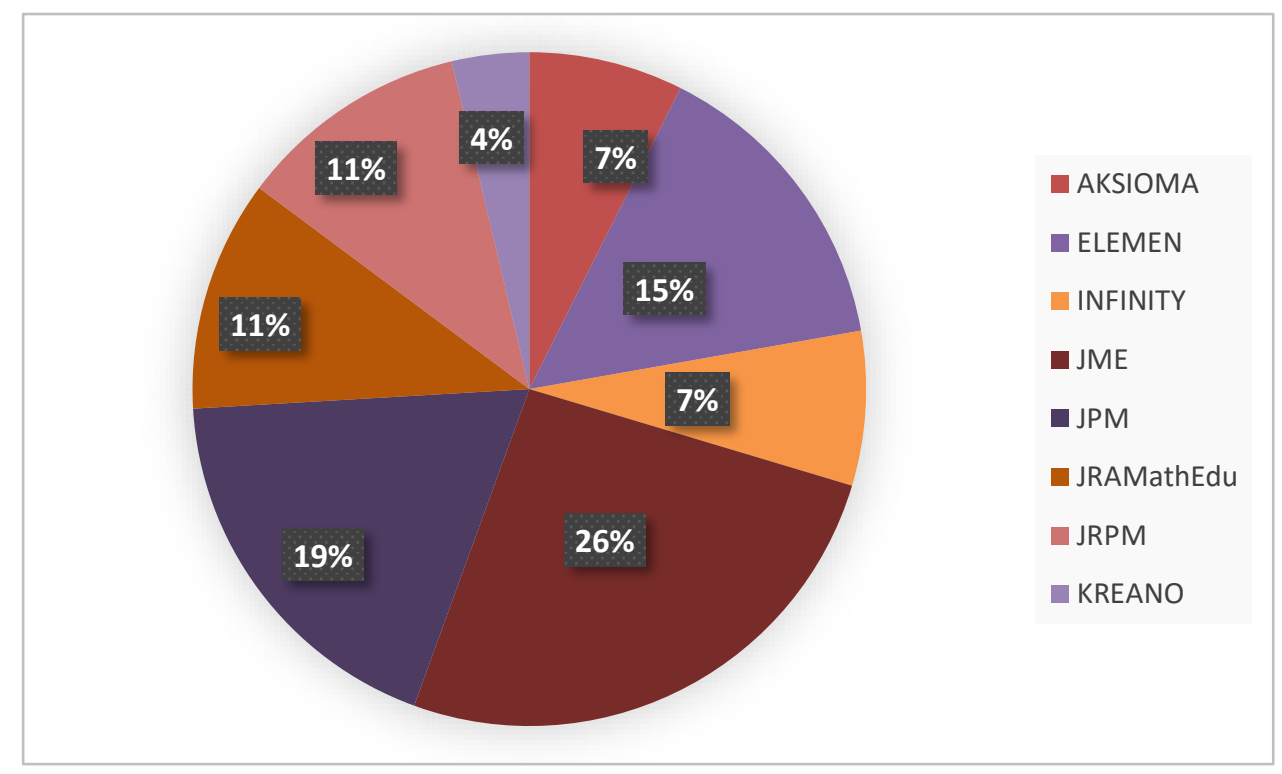

Figure 2. Number of PISA's articles in each Journal

The Development Trend of PISA Model Mathematical Problem Research in Various Journals in Indonesia

Silvia, Zulkardi, and Darmawijoyo (2011) conducted the first publication in research on developing mathematical problems with the PISA model, entitled Development of PISA Model Mathematical Problems on Uncertainty Content to Measure Junior High School Students' Mathematical Problem-Solving Ability. This article is published in Jurnal Pendidikan Matematika (JPM). This study aims to produce mathematical tasks that are valid, practical, and have a potential effect in solving mathematical problems.

There are only 9 articles of research on the development of mathematical problems in the PISA model for the period 2016-2019, which are scattered in four journals, namely Elemen, JME, JRAMathEdu, and KREANO. The articles were published in 2016 and 2019 with one article from the Elemen journal and one article from the KREANO journal published 
in 2016. Whereas in 20196 articles were published in the JME journal and one article was published by JRAMathEdu. Journals that published articles on the development of PISA model math problems over the past five years are shown in Figure 3. It can be seen that the JME journal publishes the most research articles on the development of math problems with the PISA model, which is $67 \%$.

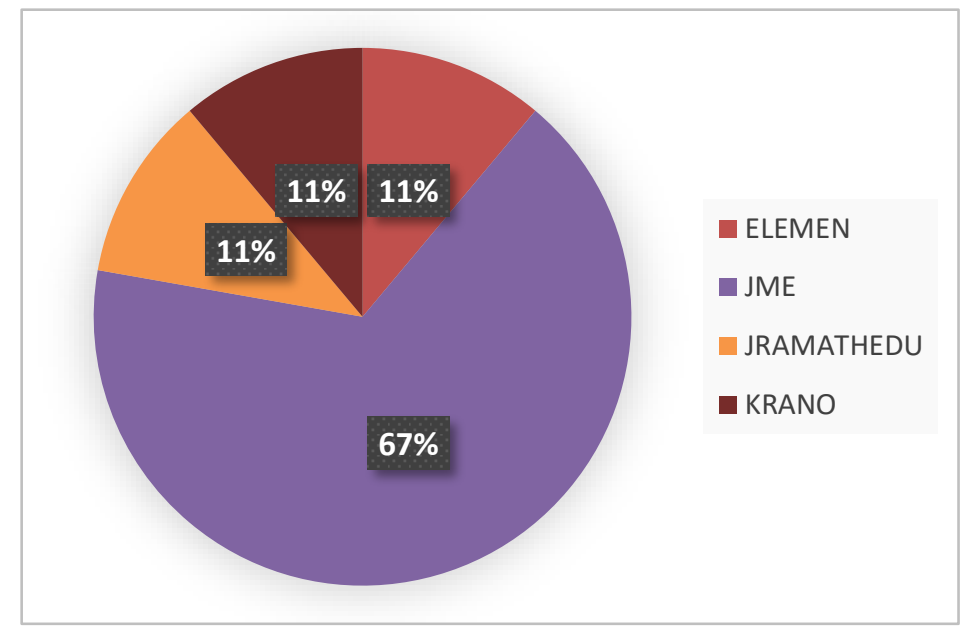

Figure 3. The number of research articles on the development of math problems using the PISA model

\section{Research Focus on PISA Articles in Indonesia}

Research on PISA has been widely carried out in Indonesia. The first research was conducted by Stacey in 2011 in which the article was published in the JME. During the last 5 years, 2016-2020, there were 27 articles about PISA. This research has various research focuses including the development of PISA model math problems, analysis of student difficulties in working on PISA questions, analysis of errors in solving PISA model questions, developing teaching materials based on PISA measurements, analyzing students' mathematical abilities, analyzing teaching materials, analyzing PISA data, and student responses to questions on the PISA model.

The focus of research on the analysis of students' mathematical abilities and the development of mathematical problems with the PISA model is the focus of research that is often used with the same percentage, namely $33 \%$. The focus of research on the analysis of mathematical abilities is scattered in almost all journals except JRAMathEdu and KREANO. The development of the PISA model math problems also varies, namely the development of questions using content and context. More than half of the articles on the development of PISA model math problems were found in the JME, while other articles were scattered in the Elemen, JRAMathEdu, and Kreano. In the third position, there is a research 
focus in the form of developing teaching materials based on PISA measurements by $11 \%$. The development of teaching materials includes the development of sharing tasks and jumping tasks and the development of the Mathematics Literacy Task. Then the focus of research on error analysis, practice, teaching materials, and student responses occupies a minority position. The focus of PISA research in Indonesia can be seen in Figure 4.

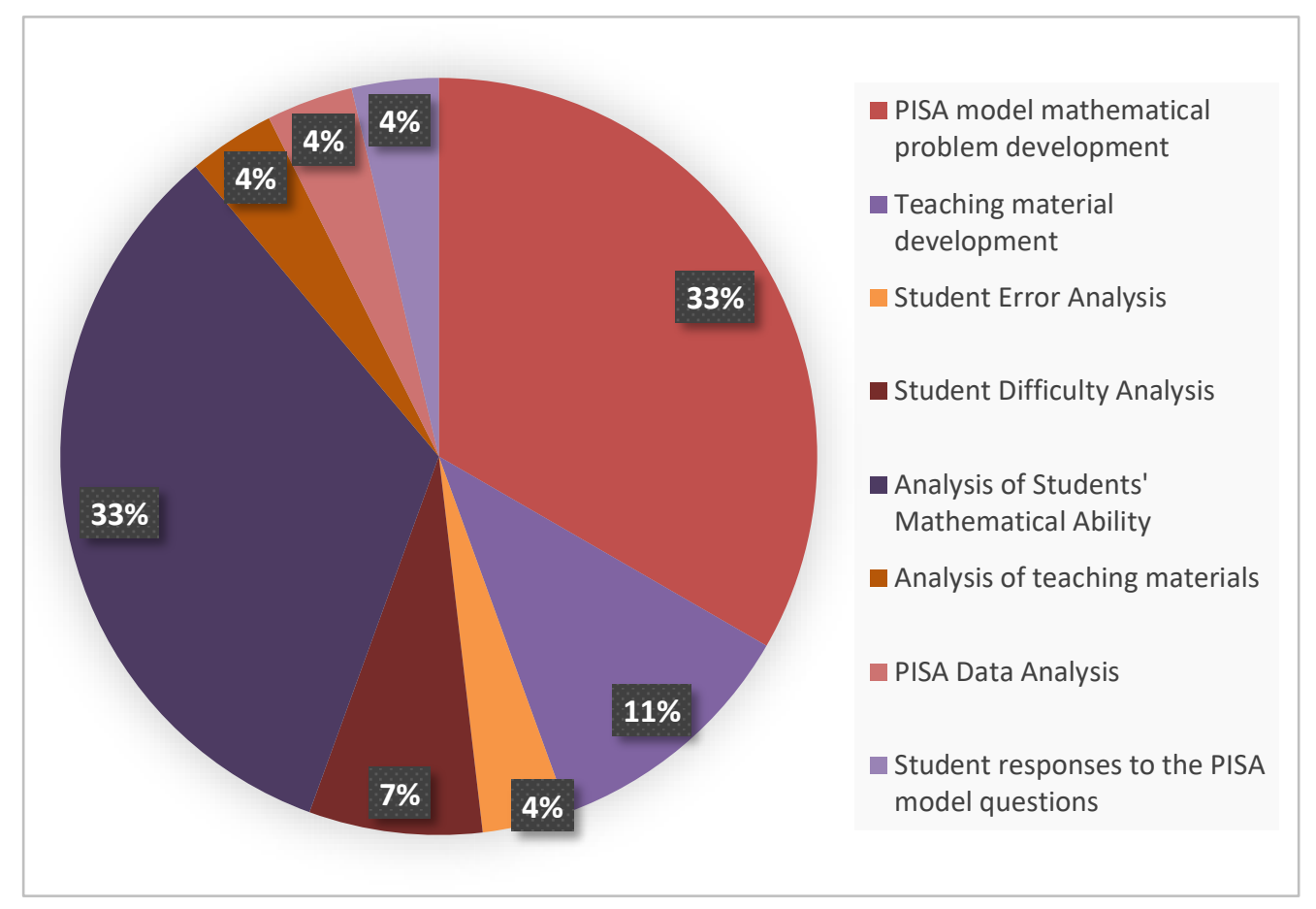

Figure 4. PISA's research focus in Indonesia

Figure 4 shows that the focus of the problem that is a minority in PISA research is student error analysis, student difficulty analysis, teaching material analysis, PISA data analysis, and student responses to PISA model questions. The focus of this problem is a recommendation for the next PISA research trend because not many have researched it with a focus on this problem. Apart from being seen from the results of the presentation, the trend of the focus of the problem has contributed to the evaluation of learning such as getting students accustomed to working on PISA type questions based on the results of research conducted by Candra, Zulkardi, and Yusuf (2017) that experienced difficulties in working on PISA level 4, 5 , and 6 questions because students have difficulty understanding, transforming real problems into mathematical forms. Although the focus of the problem of developing mathematical problems with the PISA model and analyzing students' mathematical abilities has been widely researched, it is undeniable that they can still be the focus of further PISA research problems. 


\section{Research Methods used in PISA Research in Indonesia}

The PISA articles in 8 journals are the result of joint research with various methods. The research method used includes design research, descriptive research, qualitative descriptive research, qualitative research, surveys, exploratory studies, and mixed methods.

The data show that half of PISA research uses the design research method with development studies. It reached $44 \%$. Almost all sample journals have articles with research design research methods except JRPM. Research using the design research method is $50 \%$ in JME journals, then the rest is spread in other journals with a percentage of around $8 \%$ except JRPM. In other words, almost all journals about PISA used the design research method. The second-largest research method used by PISA researchers is the qualitative descriptive method. The number of articles using the qualitative descriptive method in the Elemen journal was $50 \%$, and in the Aksioma and JRAMathEdu journals, as much as $25 \%$, respectively. The third, fourth, and fifth largest research methods are qualitative research, descriptive research, and survey research, which have the same percentage, namely $11 \%$. The number of articles with qualitative research methods is in the journal Elemen and JPM. Descriptive research methods are available in JRPM and JPM, and survey research methods are available in JRPM and JME. Meanwhile, the research methods that occupy the minority position are exploratory studies and mixed methods.

Few PISA articles published in Indonesian journals employs both methods. Based on the analysis results, the domain of the research method is articles from all journals containing PISA articles using design research, followed by qualitative descriptive, qualitative research, descriptive research, and survey research. From all the research methods used in the article, PISA in Indonesia can be seen in Figure 5.

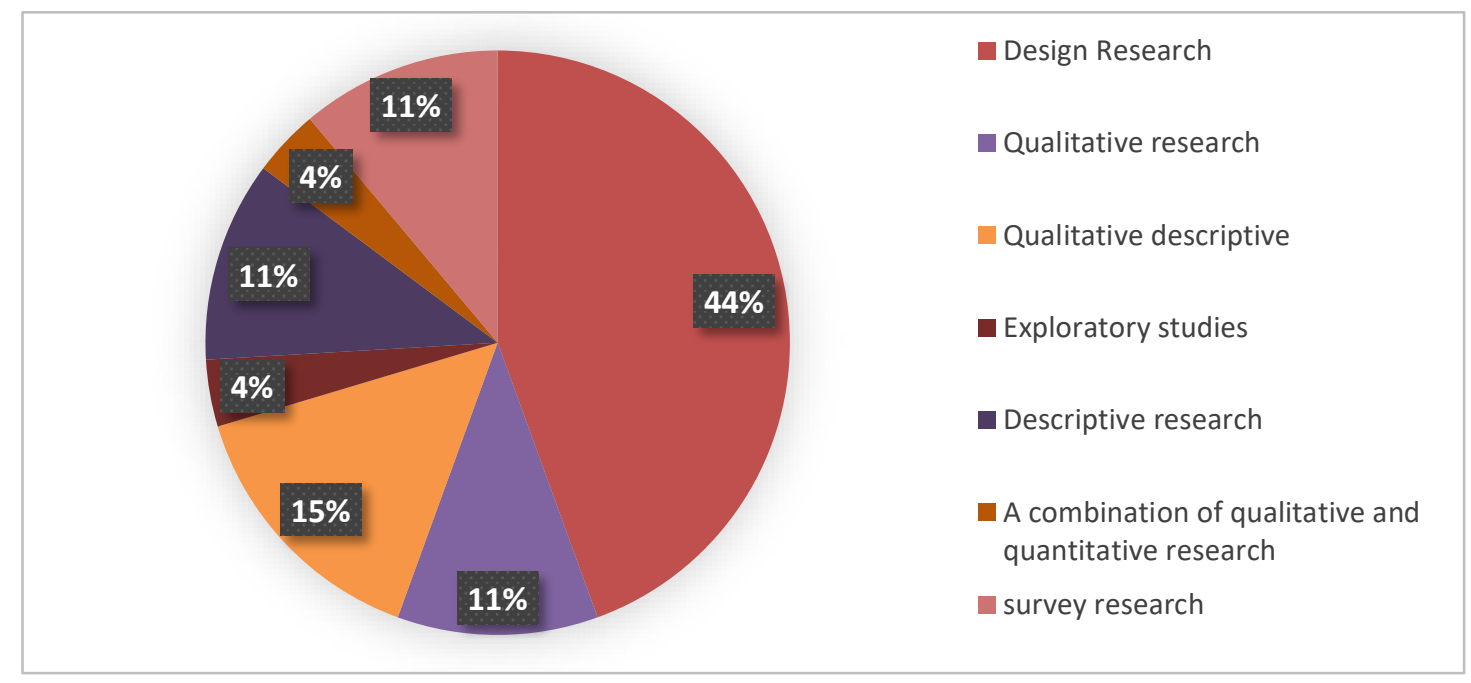

Figure 5. Research Method of PISA in Indonesia 
Design research dominates the PISA research method in Indonesia. Because it is in accordance with the results of the focus of PISA research that the development of PISA model math problems and the development of teaching materials has a number of presentations, it reached $44 \%$. The result of this presentation is the highest presentation compared to other research focuses.

Although design research has dominated PISA research in Indonesia for the last five years, the authors predict that research with the PISA design research method will still be in demand by PISA researchers. Zulkardi and Putri (2006) explained that a teacher is required to be able to design questions in a context that is close to his life. In addition, it is also to encourage teachers to plan PISA-based learning and to design PISA-based learning evaluations (Kohar, Zulkardi, \& Darmawijoyo, 2014).

\section{PISA Research Subjects in Indonesia}

PISA stands for "Program for International Student Assessment", organized by the OECD together with a group of participating countries, including Indonesia. The first survey was conducted in 2000, and then every 3 years thereafter. To better compare student performance internationally, PISA targets students of a specific age, namely those between 15 years 3 months and 16 years 2 months at the time of assessment and having completed 6 years of formal schooling (OECD, 2017). This age determination allows PISA to consistently compare the knowledge and skills of individuals born in the same year and still in school at 15 years of age.

PISA articles in 8 journals have varied research subjects. There are six research subjects including students in grade 6 elementary school, class VIII, class IX, class X, students from 3 countries, and teachers. The majority of PISA research subjects are students of class IX and X where at that level the students are 15 years old. The research subjects of class IX and X students each had the same percentage, namely 38\%. Then grade VIII students have a presentation of $12 \%$, the subject is used in the journals JRAMathedu, Infinity, Aksioma with one article each. Then the research subjects that are rarely used are elementary school students, teachers, and students from 3 countries. This is evidenced by the percentage of less than 5\%. PISA research subjects in Indonesia can be seen in Figure 6. 


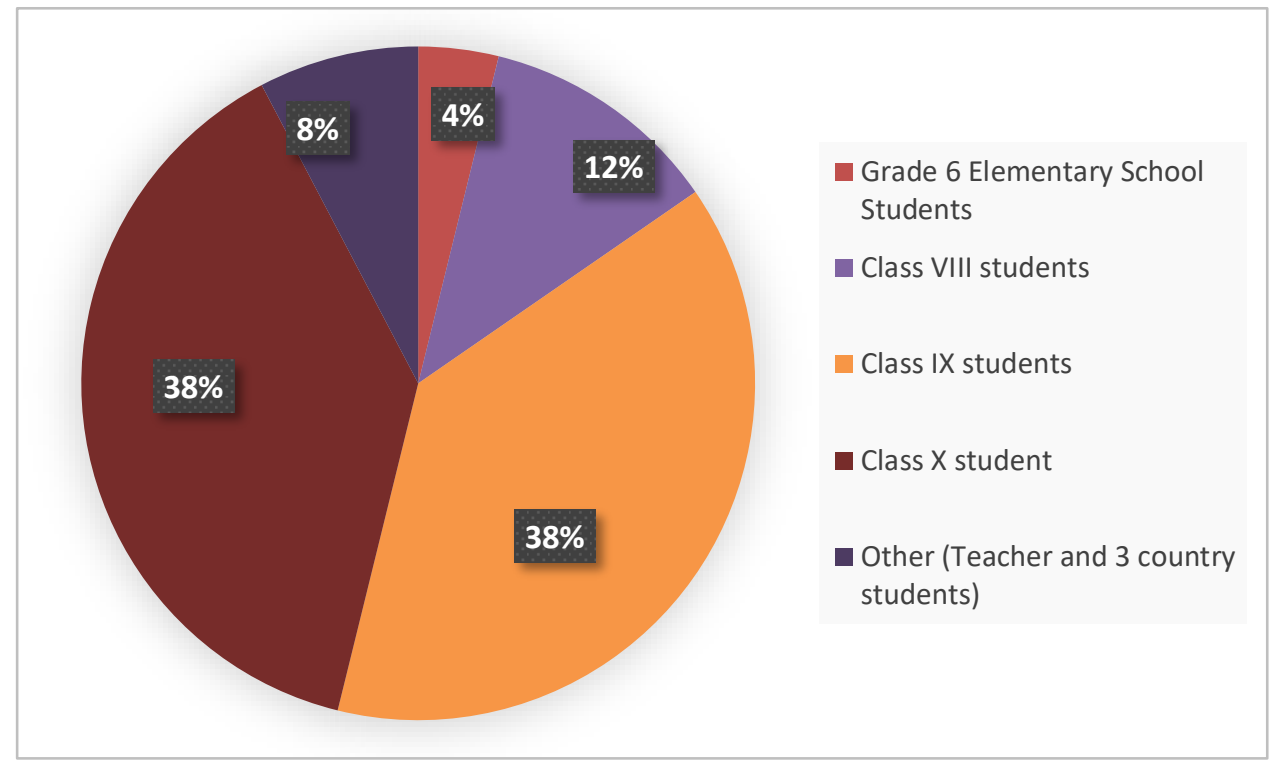

Figure 6. PISA's Research Subjects in Indonesia

It can be seen that the PISA research subjects are not only 15-year-old students, but elementary school students and teachers are also the subjects of PISA research in Indonesia. Although the PISA assessment is given to 15-year-old students, the research subjects related to PISA are not only limited to that age. Like the research subject, namely the teacher can be a recommendation for the next PISA research subject trend

Apart from being seen from the percentage results, using the teacher's subject in PISA research based on the results of Zulkardi and Putri's research (2020) provides benefits, such as teachers get a lot of new things about math problems with PISA characteristics, how to design learning evaluations with PISA characteristics, and finding contexts that are interesting to use in the problem of PISA characteristics. Then, the subject of elementary school students also provides benefits such as the results of a survey conducted by Ekawati, Susanti, \& Cheng (2020), namely the Mathematics Literacy Test (MLT) which is applied to elementary students. It is highly recommended in designing learning so that students have more opportunities to learn and solve mathematics literacy problems

\section{Content used in the PISA Model Mathematical Problem Development Research in Indonesia}

The purpose of PISA is to assess mathematical literacy skills, so a structure for knowledge of mathematical content is proposed based on mathematical phenomena that underlie broad problems (OECD, 2017). The national mathematics curriculum is also designed to equip students with knowledge and skills that address mathematical 
phenomena. A series of content categories that reflect a range of mathematical phenomena are change and relationships, space and shape, quantity, uncertainty and data.

The mathematical content that is often used in the development of math problems in the PISA model is uncertainty and data content, which is as much as $45 \%$. Then, the quantity and pace and shape content have the same percentage, which is around $22 \%$. Meanwhile, content that is rarely used is change and relationship. However, many kinds of researches in developing mathematical model problems do not include the content used. The content used in the research on the development of mathematical problems with the PISA model can be seen in Figure 7.

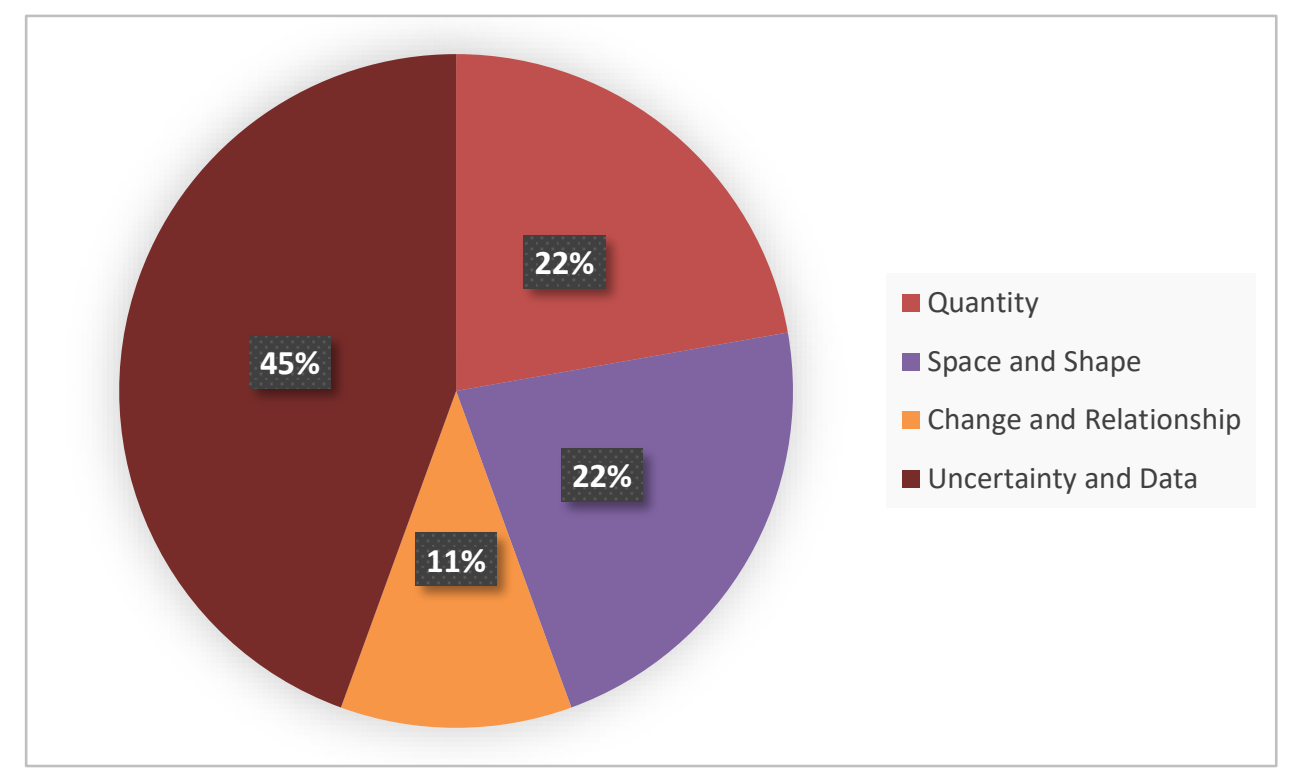

Figure 7. The content used in the development of PISA model math problems

The content of change and relationship is content that is rarely used in research on developing mathematical problems using the PISA model. In mathematics, change and relationships are associated with the function algebra, equations and inequalities, the collection of data and graphs. This content can be a recommendation for research trends in the development of math problems using the PISA model using content because it can be seen from Figure 7 that not of all have used this content. In addition, there are many contexts in everyday life that can be used to develop PISA model questions with change and relationship content. For example, the relationship between sales and income earned and the relationship between speed and distance. On the other hand, Simalango, Darmawijoyo, and Aisya (2018) stated that students still have difficulty solving PISA questions with change and relationship content, so it is necessary to develop a PISA model mathematical problem with that content. 


\section{The Context used in the PISA Model Mathematical Problem Development Research in}

\section{Indonesia}

The use of multiple contexts in the PISA survey is very important. Context is considered as an aspect of problem solving that imposes additional demands on problem solving (OECD, 2017). The use of context relates various individual interests to various situations in the 21 st century. PISA has defined four categories of context, that are personal, work, social, and scientific. Lutfianto, et al. (2013) stated that it is important to solve math problems that contain context so that students are able to analyze and respond to a problem so quickly that is needed in today's evolving era.

The use of context in PISA research in Indonesia varies considerably. Namely personal, social, scientific, and occupational. Then, the development of math problems using context has a fairly large percentage, namely $89 \%$ compared to the development of math problems using the PISA model without including a specific context. There are two specific contexts used in the development of the PISA model questions in Indonesia, namely local and sports. The local context in question is such as traditional food, traditional houses, and historical places in certain areas. This context has a percentage of $44 \%$. Research on the development of PISA model math problems with local contexts is scattered in the journals of Elemen, KREANO, and JME. While the context of sports used is football, taekwondo, bicycle and aquatic, soft tennis, volleyball, and sailing. This sport is available at the 2018 Asian Games. The development of PISA model math problems with the context of sports is only available in the JME. The context used in the research on the development of mathematics problems in the PISA model can be seen in Figure 8.

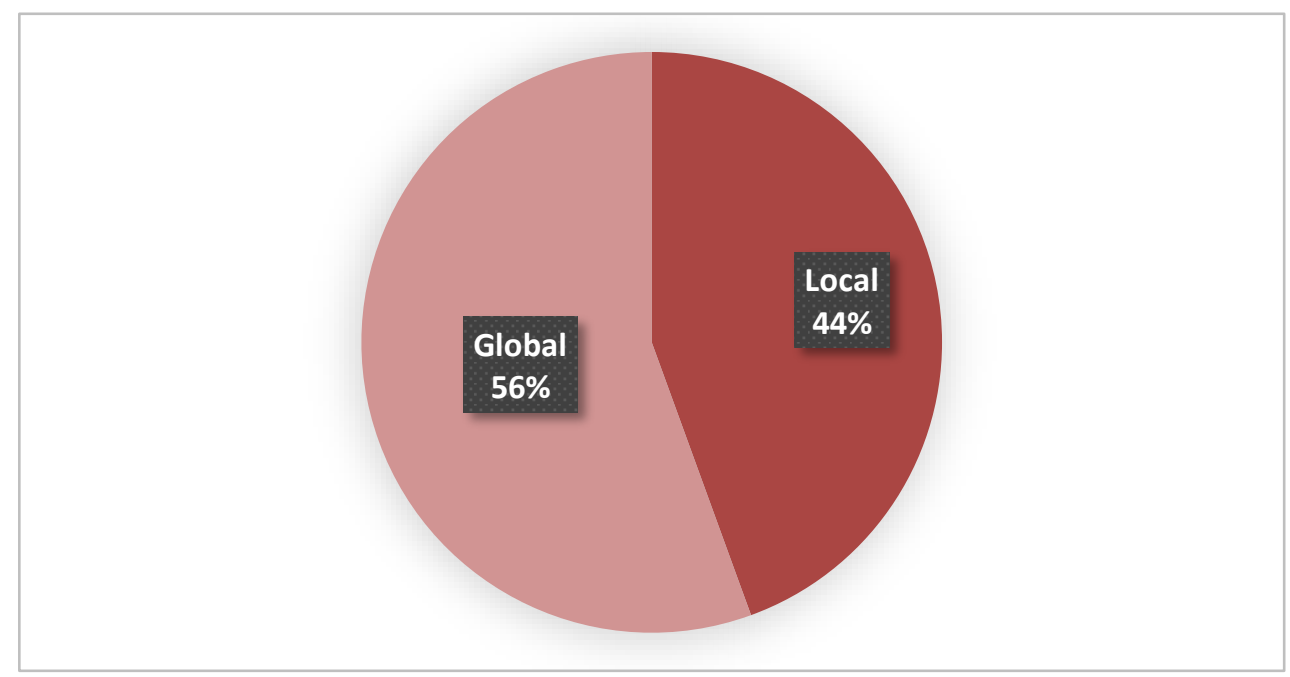

Figure 8. The context used in the development of mathematical problems with the PISA model 
The development of PISA model math problems with context will support students' mathematical literacy skills. Utilizing the local context and global can be a means to help students understand mathematical phenomena that can be linked with everyday activities, students' activities ever experienced in the surrounding environment, or activity ever observed students. It is important to incorporate the context in the surrounding environment or what they have experienced into the learning process followed by the assessment process (Charmila et al., 2016). The local context is still a recommendation for the next PISA model mathematical problem development research trend. Based on Figure 8, the phenomenon that is happening in the 2018 Asian Games so that research on the development of mathematical problems in the PISA model uses a phenomenon or event that is happening. However, the next trend in context is also undeniable using the context that is happening in this nature.

\section{The Abilities Studied in the PISA Model Mathematical Problem Development Research in}

\section{Indonesia}

The purpose of research on mathematics education is to have various types of mathematical abilities. PISA in the mathematics domain measures mathematics assessments in which there are seven basic abilities of PISA mathematics. This ability underlies the mathematical process as a framework for assessing mathematical literacy. PISA defines mathematical literacy as an individual's capacity to formulate, use, and interpret mathematics in various contexts. Mathematical literacy includes mathematical reasoning skills, using concepts, procedures, facts. and mathematical tools to describe, explain and predict phenomena. In the PISA assessment, mathematical literacy is demonstrated through student's ability to analyze, reason, and communicate effectively when they pose, solve, and interpret mathematical problems that involve quantitative, spatial, probabilistic, or other concepts (OECD, 2009).

Various math abilities are measured in PISA research in Indonesia. Mathematical literacy skills dominate with a percentage of $63 \%$. In the mathematics problem development research, the most of measured mathematical ability was also the mathematical literacy ability, reached $78 \%$. Meanwhile, other abilities are the basic abilities of mathematics and mathematical reasoning with each percentage of $11 \%$. The ability that is measured in the PISA model mathematical problem development research can be seen in Figure 9. 


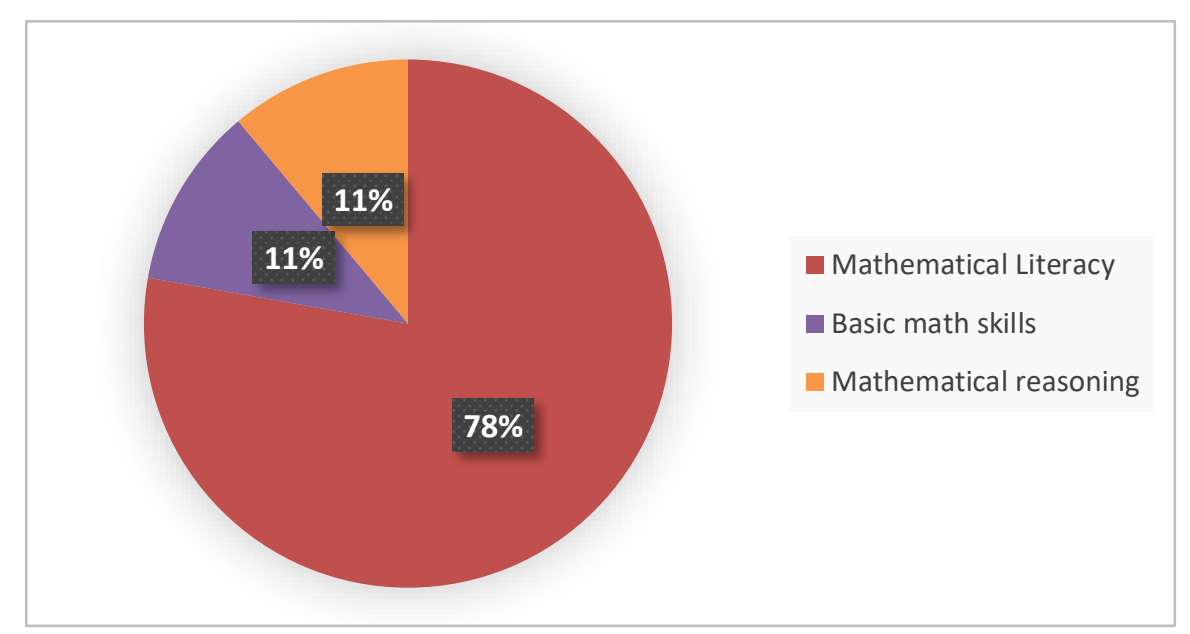

Figure 9. The ability that is measured in the development of a PISA model math problem

Figure 9 shows that mathematical literacy dominates for the abilities measured in the PISA model mathematical problem development research. It's because the relationship between PISA and mathematical literacy is that PISA tests students with tests that require skills and competencies acquired in school and can be applied to solve problems in real life in various situations through literacy skills in a mathematical context (OECD, 2019). Specific abilities such as mathematical reasoning can be a trend in measuring the next PISA model mathematical problem development research. The study conducted by Usnul et al. (2019) shows that the PISA equivalent mathematical reasoning ability problem using the developed context has a potential effect. Students are interested in it to solve the PISA identical problem.

\section{Levels of Problems used in the PISA Model of Mathematical Problem Development} Research in Indonesia

The thinking skills contained in the Regulation of the Minister of Culture of the Republic of Indonesia Number 104 of 2014 concerning Assessment of Learning Outcomes by Educators in Primary and Secondary Education are also found in PISA questions. PISA questions consist of 6 levels, namely level 1 there is the ability to remember, level 2 the ability to understand, level 3 the ability to apply, level 4 the ability to analyze, level 5 the ability to evaluate, and level 6 the ability to create (Simalango et al, 2018).

PISA articles in 8 journals examining various levels of questions. The level of questions that have been tested the most is level 4 and level 5, which are 24\% respectively. Likewise, the level of questions developed in the research on the development of mathematical problems with the PISA model, level 4 and level 5 occupied the top ranks, namely 25\% respectively. Then level 3 and level 6 also have the same percentage, namely 
17\%. Meanwhile, the level of questions that are rarely developed is level 1 and level 2, namely $8 \%$. The level of questions developed or used in the PISA model mathematical problem development research can be seen in Figure 10.

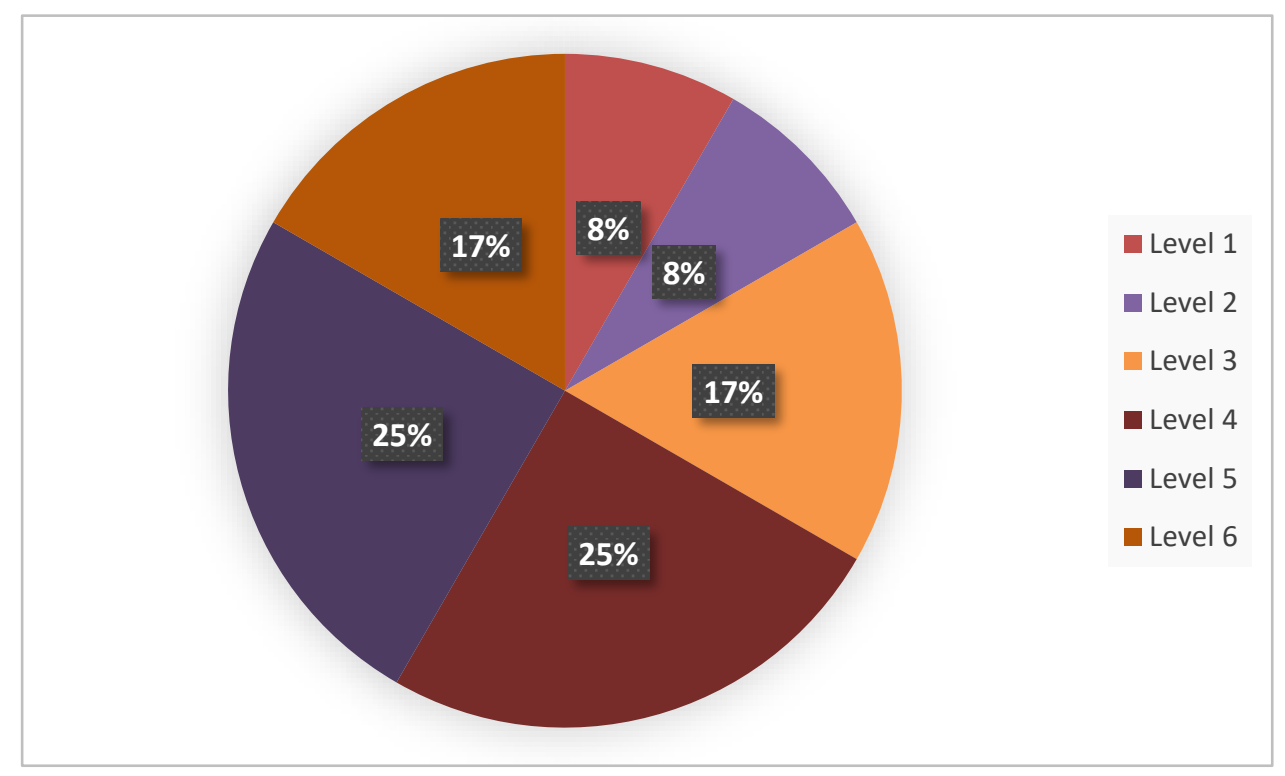

Figure 10. The level of questions used in the development of PISA model math problems

The results of this percentage are following those Indonesian students who can only answer PISA questions at levels 1, 2, and 3. So, the levels that are mainly developed and tested are level 4 and level 5-recommendations for trends related to the level of questions designed for research. The next PISA model math problem's development is level 6 because, based on the research results, Indonesian students can only answer PISA questions level 1, 2, and 3 (Simalango et al., 2018). Lastly, based on Figure 10, questions level 4 and 5 have been developed a lot, but question level 6 has not been designed much.

\section{PISA Research Articles in Indonesia during 2016-2020}

A total of 27 PISA research articles in Indonesia from 8 journals accredited by the Ministry of Research, Technology, and Higher Education answered the question that PISA research in Indonesia is still alive. Publications in journals prove that PISA research activities are an innovation in mathematics learning. Journals can be used as a medium for stakeholders such as teachers, lecturers, students, researchers, and book authors to receive and share their findings.

In the past 5 years, more than PISA research is development research. More than research development is the development of PISA model math problems. More than that 
is the development of teaching materials. The product produced from development research is a PISA model mathematical problem that is valid, practical, and has potential effects (Putra, Zulkardi, \& Hartono, 2016; Dasaprawira, Zulkardi, \& Susanti, 2019; Efriani, Putri, \& Hapizah, 2019; Jannah, Putri, \& Zulkardi, 2019; Maharani, Putri, \& Hartono, 2019; Rawani, Putri, \& Hapizah, 2019; Yansen, Putri, Zulkardi, \& Fatimah, 2019; Lestari \& Putri, 2020; Usnul, Johar, \& Sofyan, 2019; Putra, Zulkardi, \& Hartono, 2016) and learning tools (Utami \& Nirawati, 2018; Ekawati, Susanti, \& Chen, 2020; Zulkardi \& Putri, 2020).

Table 1 is a classification based on the focus of PISA research in Indonesia. Therefore, the researchers hope that this table can be used as a guideline for assessing the distribution of PISA studies over the $2016-2020$ period.

Table 1. Resume of PISA Research Articles in Indonesia

\begin{tabular}{|c|c|c|c|c|}
\hline No & $\begin{array}{l}\text { Research } \\
\text { Focus }\end{array}$ & Content & Context & References \\
\hline \multirow[t]{5}{*}{1} & \multirow{5}{*}{$\begin{array}{l}\text { PISA model } \\
\text { mathematical } \\
\text { problem } \\
\text { development }\end{array}$} & Quantity & Local & $\begin{array}{l}\text { (Putra, Zulkardi, \& } \\
\text { Hartono, 2016) }\end{array}$ \\
\hline & & $\begin{array}{l}\text { Space and } \\
\text { Shape }\end{array}$ & Global & (Efriani \& Putri, 2019) \\
\hline & & $\begin{array}{l}\text { Uncertainty } \\
\text { and Data }\end{array}$ & Global & $\begin{array}{l}\text { (Jannah \& Putri, 2019; } \\
\text { Maharani, Putri, \& } \\
\text { Hartono, 2019; Yansen \& } \\
\text { Putri, 2019) }\end{array}$ \\
\hline & & Other & Local & $\begin{array}{l}\text { (Putra, Zulkardi, \& } \\
\text { Hartono, 2016; } \\
\text { Dasaprawira, 2019; Usnul, } \\
\text { Johar, \& Sofyan, 2019) }\end{array}$ \\
\hline & & & Global & (Rawani \& Putri, 2019) \\
\hline \multirow[t]{3}{*}{2} & \multirow{3}{*}{$\begin{array}{l}\text { Teaching } \\
\text { material } \\
\text { development }\end{array}$} & $\begin{array}{l}\text { Quantity } \\
\text { Uncertainty }\end{array}$ & $\begin{array}{c}\text { Social } \\
\text { Personal }\end{array}$ & $\begin{array}{l}\text { (Ekawati, Susanti, \& } \\
\text { Chen, 2020) }\end{array}$ \\
\hline & & $\begin{array}{l}\text { and data } \\
\text { Space and } \\
\text { Shape }\end{array}$ & $\begin{array}{l}\text { Occupational } \\
\text { Science }\end{array}$ & \\
\hline & & Other & Other & $\begin{array}{l}\text { (Utami, \& Nirawati, 2018; } \\
\text { Zulkardi \& Putri, 2020) }\end{array}$ \\
\hline \multirow[t]{2}{*}{3} & \multirow[t]{2}{*}{$\begin{array}{l}\text { Student Error } \\
\text { Analysis }\end{array}$} & Other & $\begin{array}{l}\text { Social } \\
\text { Personal }\end{array}$ & (Sari \& Valentino, 2017) \\
\hline & & & $\begin{array}{l}\text { Occupational } \\
\text { Science }\end{array}$ & \\
\hline
\end{tabular}




\begin{tabular}{|c|c|c|c|c|}
\hline \multirow[t]{2}{*}{4} & \multirow{2}{*}{$\begin{array}{l}\text { Student } \\
\text { Difficulty } \\
\text { Analysis }\end{array}$} & $\begin{array}{l}\text { Change and } \\
\text { Relationship }\end{array}$ & Other & $\begin{array}{l}\text { (Simalango, Darmawijoyo, } \\
\text { \& Aisyah, 2018) }\end{array}$ \\
\hline & & Other & Other & $\begin{array}{l}\text { (Dewi, Zulkardi, \& } \\
\text { Yusuf, 2015) }\end{array}$ \\
\hline \multirow[t]{6}{*}{5} & \multirow[t]{6}{*}{$\begin{array}{l}\text { Analysis of } \\
\text { Students' } \\
\text { Mathematical } \\
\text { Ability }\end{array}$} & $\begin{array}{l}\text { Space and } \\
\text { Shape }\end{array}$ & $\begin{array}{c}\text { Social } \\
\text { Personal } \\
\text { Occupational } \\
\text { Science }\end{array}$ & $\begin{array}{l}\text { (Khaerunisak, Kartono, } \\
\text { Hidayah, \& Fahmi, 2017) }\end{array}$ \\
\hline & & $\begin{array}{l}\text { Quantity, } \\
\text { Space and } \\
\text { Shape }\end{array}$ & Personal & (Hartatiana, 2020) \\
\hline & & $\begin{array}{l}\text { Quantity } \\
\text { Change and } \\
\text { Relationship } \\
\text { Space and } \\
\text { Shape } \\
\text { Uncertainty } \\
\text { and Data }\end{array}$ & $\begin{array}{c}\text { Social } \\
\text { Personal } \\
\text { Occupational } \\
\text { Science }\end{array}$ & (Wulandari, 2018) \\
\hline & & Quantity & Other & (Setyawati \& Ratu, 2019) \\
\hline & & Other & Local & (Lestari \& Putri, 2020) \\
\hline & & Other & Other & $\begin{array}{l}\text { (Nilasari \& } \\
\text { Anggreini, 2019; Arfiana \& } \\
\text { Wijaya, 2018; Annizar, } \\
\text { Maulyda, Khairunnisa, \& } \\
\text { Hijriani, 2020; Hamidy \& } \\
\text { Jailani, 2019) }\end{array}$ \\
\hline 6 & $\begin{array}{l}\text { Analysis of } \\
\text { teaching } \\
\text { materials }\end{array}$ & $\begin{array}{l}\text { Quantity } \\
\text { Change and } \\
\text { Relationship } \\
\text { Space and } \\
\text { Shape } \\
\text { Uncertainty } \\
\text { and Data }\end{array}$ & $\begin{array}{c}\text { Social } \\
\text { Personal } \\
\text { Occupational } \\
\text { Science }\end{array}$ & $\begin{array}{l}\text { (Murdaningsih \& } \\
\text { Murtiyasa, 2016) }\end{array}$ \\
\hline 7 & $\begin{array}{l}\text { PISA Data } \\
\text { Analysis }\end{array}$ & $\begin{array}{l}\text { Quantity } \\
\text { Change and } \\
\text { Relationship } \\
\text { Space and } \\
\text { Shape } \\
\text { Uncertainty } \\
\text { and Data }\end{array}$ & Other & $\begin{array}{l}\text { (Kartianom \& } \\
\text { Ndayizeye, 2017) }\end{array}$ \\
\hline
\end{tabular}




\begin{tabular}{llll}
\hline 8 & $\begin{array}{l}\text { Student } \\
\text { responses to } \\
\text { the PISA }\end{array}$ & Other & \\
model & & \\
questions & & \\
\hline
\end{tabular}

\section{Conclusion}

Researchers have summarized 27 articles in Table 1 and classifications of PISA articles in nine categories, namely trends in PISA articles in Indonesia, trends in articles on developing PISA model math problems in Indonesia, PISA research focus, research methods used, research subjects, content used in problem development. PISA model mathematics, the context used in developing the PISA model questions, students' abilities, and the level of questions. Most PISA articles are found in JME journals and are followed by JPM, with the most widely used research method being design research.

PISA research focus that is often researched is the analysis of students' abilities and PISA model mathematical questions. Therefore, most of the subjects used were nine and tengrade students who were 15 years old. However, it was also found that six-grade elementary school students were also the subject of PISA research. The majority of mathematical abilities assessed in PISA model research on mathematical problem development are mathematical literacy skills. When evaluating mathematical literacy abilities, it is necessary to consider both the content and context. Uncertainty and data are frequently used as content in PISA model math problems. Meanwhile, the most commonly used context is that of the sport's branch, followed by a local context.

The research findings assist future PISA researchers in determining PISA research trends and opportunities in Indonesia. The results also serve as a recommendation and providing essential information as a foundation for subsequent PISA research by giving detailed information on trends in PISA research in Indonesia over the last five years. The trends referred to are the research methods, problem focus, content, and context of the PISA research conducted in Indonesia.

\section{Acknowledgments}

The authors would like to express their gratitude to Universitas Ahmad Dahlan for its support and facilitation of this research, particularly to Dra. Sumargiyani, M.Pd., and Afit Istiandaru, S.Si., M.Pd., as the validators for this research and Uswatun Khasanah, S.Si., M.Sc., as the head of mathematics education department, for her assistance in bringing this 
research. Additionally, we would like to express our gratitude to all authors whose works cited in this paper are valuable resources and references for this paper. Finally, we would like to express our gratitude to all reviewers for their insightful comments.

\section{References}

Annizar, A. M. R., Maulyda, M. A., Khairunnisa, G. F., \& Hijriani, L. (2020). Kemampuan Pemecahan Masalah Matematis Siswa dalam Menyelesaikan Soal PISA pada Topik Geometri. Jurnal Elemen, 6(1), 39-55. https://doi.org/10.29408/jel.v6i1.1688

Arfiana, A., \& Wijaya, A. (2018). Problem Solving Skill of Students of Senior High Schools and Islamic High Schools in Tegal Regency in Solving The Problem of Pisa based on Polya's Stage. Jurnal Riset Pendidikan Matematika, 5(2), 211-222. https://doi.org/10.21831/jrpm.v5i2.15783

Calderón, A., \& Ruiz, M. (2015). A systematic literature review on serious games evaluation: An application to software project management. Computers \& Education, 87, 396-422. https://doi.org/10.1016/j.compedu.2015.07.011

Candra, A. I., Zulkardi, \& Yusuf, M. (2017). Analisis Kesulitan Siswa dalam Menyelesaikan Soal-Soal PISA Tahun 2012 Level 4, 5, dan 6 di SMP N 1 Indralaya. Jurnal Pendidikan Matematika, 11(2), 43-58. https://doi.org/10.22342/jpm.11.2.2143

Charmila, Ninik., Zulkardi, \& Darmawijoyo. (2016). Pengembangan Soal Matematika Model PISA Menggunakan Konteks Jambi. Jurnal Penelitian dan Evaluasi Pendidikan, 20(2), 198-207. https://doi.org/10.21831/pep.v20i2.7444

Dasaprawira, M. N. (2019). Developing Mathematics Questions of PISA Type Using Bangka Context. Journal on Mathematics Education, 10(2), 303-314. https://doi.org/10.22342/jme.10.2.5366.303-314

Dewi, A. I. C., Zulkardi, \& Yusuf, M. (2015). Analisis Kesulitan Siswa dalam Menyelesaikan Soal Soal PISA Tahun 2012 Level 4, 5, dan 6 Di SMP N 1 Indralaya. Unpublished Thesis. Palembang: Sriwijaya University.

Efriani, A., \& Putri, R. I. I. (2019). Sailing Context in PISA-Like Mathematics Problems. Journal on Mathematics Education, 10(2), 265-276. https://doi.org/10.22342/jme.10.2.5245.265-276

Ekawati, R., Susanti, S., \& Chen, J. C. (2020). Primary Students'Mathematical Literacy: A Case Study. Infinity Journal, 9(1), 49-58. https://doi.org/10.22460/infinity.v9i1.p49-58

Hamidy, A., \& Jailani, J. (2019). Kemampuan Proses Matematis Siswa Kalimantan Timur dalam Menyelesaikan Soal Matematika Model Pisa. Jurnal Riset Pendidikan Matematika, 6(2), 133-149. https://doi.org/10.21831/jrpm.v6i2.26679

Hartatiana, H. (2020). Kemampuan Berpikir Tingkat Tinggi Siswa SMP dalam Menyelesaikan Soal Matematika Model PISA. Jurnal Pendidikan Matematika, 14(01), 15-24. https://doi.org/10.22342/jpm.14.1.6815.15-24

Hooshyar, D., Pedaste, M., Saks, K., Leijen, Ä., Bardone, E., \& Wang, M. (2020). Open learner models in supporting self-regulated learning in higher education: A systematic literature review. Computers \& Education, 154, 103878. https://doi.org/10.1016/j.compedu.2020.103878 
Jannah, R. D., \& Putri, R. I. I. (2019). Soft Tennis and Volleyball Contexts in Asian Games for PISA-LIKE Mathematics Problems. Journal on Mathematics Education, 10(1), $157-$ 170. https://doi.org/10.22342/jme.10.1.5248.157-170

Kartianom, K., \& Ndayizeye, O. (2017). What's Wrong With The Asian and African Students' Mathematics Learning Achievement? The Multilevel Pisa 2015 Data Analysis for Indonesia, Japan, and Algeria. Jurnal Riset Pendidikan Matematika, 4(2), 200-210. https://doi.org/10.21831/jrpm.v4i2.16931

Khaerunisak, K., Kartono, K., Hidayah, I., \& Fahmi, A. Y. (2017). The Analysis of Diagnostic Assessment Result in Pisa Mathematical Literacy Based on Students SelfEfficacy in Rme Learning. Infinity Journal, 6(1), 77-94. https://doi.org/10.22460/infinity.v6i1.p77-94

Kohar, A. W., Zulkardi, \& Darmawijoyo. (2014). Investigating Students? Difficulties in Completing Mathematical Literacy Processes: A Case of Indonesian 15-Year-Old Students on PISA-Like Math Problems.

Lestari, N \& Putri, R. I. I. (2020). Using the Plaembang's Local Context in PISA-Like Mathematics Problem for Analyze Mathematics Literacy Ability of Students. Jurnal Pendidikan Matematika, 14(2), 169-182. https://doi.org/10.22342/jpm.14.2.6708.169$\underline{182}$

Lutfianto, M. (2013). Unfinished student answer in PISA mathematics contextual problem.

Lutfianto, M., \& Sari, A. F. (2017). Respon Siswa Terhadap Soal Matematika Mirip Pisa dengan Konteks Berintegrasi Nilai Islam. Jurnal Elemen, 3(2), 108-117. https://doi.org/10.29408/jel.v3i2.342

Maharani, L., Putri, R. I. I., \& Hartono, Y. (2019). Aquatic in Asian Games: Context of PisaLike Mathematics Problem. Journal on Mathematics Education, 10(3), 459-470. https://doi.org/10.22342/jme.10.3.5252.459-470

Murdaningsih, S., \& Murtiyasa, B. (2016). An Analysis on Eight Grade Mathematics Textbook of New Indonesian Curriculum (K-13) Based on Pisa's Framework. JRAMathEdu (Journal of Research and Advances in Mathematics Education), 1(1), 1427. https://doi.org/10.23917/jramathedu.v1i1.1780

Murdaningsih, S., \& Murtiyasa, B. (2016). An Analysis on Eight Grade Mathematics Textbook of New Indonesian Curriculum (K-13) Based on Pisa's Framework. JRAMathEdu (Journal of Research and Advances in Mathematics Education), 1(1), 14-27. https://doi.org/10.23917/jramathedu.v1i1.1780

Nilasari, N. T., \& Anggreini, D. (2019). Kemampuan Literasi Matematika Siswa dalam Menyelesaikan Soal PISA Ditinjau dari Adversity Quotient. Jurnal Elemen, 5(2), 206219. https://doi.org/10.29408/jel.v5i2.1342

OECD (2009). PISA 2009 Assesment Framework-Key.Paris: OECD Publishing.

OECD. (2010). PISA 2009 Results: What Students Know and Can Do - Student Performance in Reading, Mathematics and Science (Volume I). Paris: OECD Publishing.

OECD. (2016). PISA 2015 Results: Excelence and Equity in Education (Volume I). Paris: OECD Publishing.

OECD. (2017). PISA 2015 Assesment and Analytical Framework. Paris: OECD Publishing. https://doi.org/10.1787/9789264281820-en 
OECD. (2019). PISA 2018 Assessment and Analytical Framework. Paris: OECD Publishing. https://doi.org/10.1787/b25efab8-en

Park, J., Bouck, E. C., \& Josol, C. K. (2020). Maintenance in Mathematics for Individuals with Intellectual Disability: A Systematic Review of Literature. Research in Developmental Disabilities, 105, 103751. https://doi.org/10.1016/j.ridd.2020.103751

Parris, D. L., \& Peachey, J. W. (2013). A systematic literature review of servant leadership theory in organizational contexts. Journal of Business Ethics, 113(3), 377-393. https://doi.org/10.1007/s10551-012-1322-6

Prahmana, R. C. I., Sagita, L., Hidayat, W., \& Utami, N. W. (2020). Two Decades of Realistic Mathematics Education Research in Indonesia: A Survey. Infinity Journal, 9(2), 223246. https://doi.org/10.22460/infinity.v9i2.p223-246

Putra, Y. Y., Zulkardi, Z., \& Hartono, Y. (2016). Pengembangan Soal Matematika Model PISA Konten Bilangan untuk Mengetahui Kemampuan Literasi Matematika Siswa. Jurnal Elemen, 2(1), 14-26. https://doi.org/10.29408/jel.v2i1.175

Putra, Y. Y., Zulkardi, Z., \& Hartono, Y. (2016). Pengembangan Soal Matematika Model Pisa Level 4, 5, 6 Menggunakan Konteks Lampung. Kreano, Jurnal Matematika KreatifInovatif, 7(1), 10-16. https://doi.org/10.15294/kreano.v7i1.4832

Rawani, D., \& Putri, R. I. I. (2019). PISA-Like Mathematics Problems: Using Taekwondo Context of Asian Games. Journal on Mathematics Education, 10(2), 277-288. https://doi.org/10.22342/jme.10.2.5243.277-288

Sari, Y. M., \& Valentino, E. (2017). An Analysis of Students Error in Solving PISA 2012 and Its Scaffolding. JRAMathEdu (Journal of Research and Advances in Mathematics Education), 1(2), 90-98. https://doi.org/10.23917/jramathedu.v1i2.3380

Setyawati, R. D., \& Ratu, N. (2019). Lapisan Pemahaman Konsep Matematika dalam Soal Pisa pada Siswa Sma Kelas X. AKSIOMA: Jurnal Program Studi Pendidikan Matematika, 8(1), 193-204. https://doi.org/10.24127/ajpm.v8i1.1890

Silvia, E. Y., Zulkardi, Z., \& Darmawijoyo, D. (2011). Pengembangan Soal Matematika Model PISA pada Konten Uncertainty untuk Mengukur Kemampuan Pemecahan Masalah Matematika Siswa Sekolah Menengah Pertama. Jurnal Pendidikan Matematika, 5(1), 121685. https://doi.org/10.22342/jpm.5.1.335.

Simalango, M. M., Darmawijoyo, D., \& Aisyah, N. (2018). Kesulitan Siswa dalam Menyelesaikan Soal-Soal Pisa pada Konten Change and Relationship Level 4, 5, dan 6 di SMPN 1 Indralaya. Jurnal Pendidikan Matematika, 12(1), 43-58. https://doi.org/10.22342/jpm.12.1.4246.43-58

Stacey, K. (2011). The PISA View of Mathematical Literacy in Indonesia. Journal on Mathematics Education, 2(2), 95-126. https://doi.org/10.22342/jme.2.2.746.95-126

Suprapto, N. (2016). What should educational reform in Indonesia look like?-Learning from the PISA science scores of East-Asian countries and Singapore. Asia-Pacific Forum on Science Learning \& Teaching, 17(2), 1-21. https://www.eduhk.hk/apfslt/

Thien, L. M., Darmawan, I. G. N., \& Ong, M. Y. (2015). Affective characteristics and mathematics performance in Indonesia, Malaysia, and Thailand: what can PISA 2012 data tell us?.Large-scale Assessments in Education, 3(1), 1-16. https://doi.org/10.1186/s40536-015-0013-z 
Usnul, U., Johar, R., \& Sofyan, H. (2019). Potential Effect of PISA Equivalent Questions Using the Context of Aceh Traditional Houses. JRAMathEdu (Journal of Research and $\begin{array}{llll}\text { Advances in } & \text { Mathematics }\end{array}$ https://doi.org/10.23917/jramathedu.v4i2.8362

Utami, C., \& Nirawati, R. (2018). Pengembangan Kemampuan Literasi Matematis Melalui Model PJBL dengan Pendekatan Realistic Saintific dan Pengukuran Berbasis PISA. AKSIOMA: Jurnal Program Studi Pendidikan Matematika, 7(3), 345-355. https://doi.org/10.24127/ajpm.v7i3.1543

Wulandari, N. F. (2018). Mathematics Skill of Fifteen Years Old Students in Yogyakarta in Solving Problems Like PISA. Journal on Mathematics Education, 9(1), 129-144. https://doi.org/10.22342/jme.9.1.4231.129-144

Yansen, D., Putri, R.I.I., Zulkardi, \& Fatimah, S. (2019). Developing PISA-Like Mathematics Problems on Uncertainty and Data Using Asian Games Football Context. Journal on Mathematics Education, 10(1), 37-46. https://doi.org/10.22342/jme.10.1.5249.37-46

Zulkardi \& Putri, R. I. I. (2020). Supporting Mathematics Teachers to Develop Jumping Task Using PISA Framework (JUMPISA). Jurnal Pendidikan Matematika, 14(2), 199-210. https://doi.org/10.22342/jpm.14.2.12115.199-210

Zulkardi, Z., \& Putri, R. I. I. (2006). Mendesain sendiri soal kontekstual matematika. Proceedings of KNM 13, pp. 1-7, Semarang: UNNES. 